\title{
Perjanjian Kredit Antara Bank Dengan Pelaku Usaha Kecil dan Menengah Dalam Meningkatkan Perekonomian Masyarakat
}

\begin{abstract}
Ahmad Munawir Siregar*
Abstrak

Pelaku Usaha Kecil Dan Menengah (UKM) di Indonesia masih banyak yang sulit untuk mendapatkan modal dari bank, dikarenakan tidak mengerti isi perjanjian dan tidak memiliki agunan. Rumusan masalah penelitian ini bagaimana perjanjian kredit antara bank dan pelaku UKM, dan tujuan penelitian yaitu untuk mendapat informasi tentang perjanjian kredit antara bank dan pelaku. Kegunaan dapat memberikan infromasi kepada Pelaku Usaha Kecil Dan Menengah (UKM) Metode penelitian yaitu yuridis normatif. Hasil penelitian menunjukkan bahwa pelaksanaan perjanjian yang dilakukan oleh BRI KCP Jati Asih tidak lepas dari ketentuan KUHPerdata. Meskipun perjanjian kredit tidak diatur dengan jelas dalam KUHPerdata, namun unsur-unsur perjanjian kredit tidak boleh lepas dari ketentuan yang ada dalam KUHPerdata. Perjanjian yang dilakukan oleh pihak bank dengan pelaku UKM menggunakan perjanjian baku (standart contract). Dengan perjanjian baku maka terjadi ketidak seimbangan posisi antara bank dengan debitur, dan juga klausul-klausul yang ada dalam perjanjian ada yang memberatkan debitur. Kesimpulan bahwa dalam pelaksanaan pemberian kredit bank selalu menempuh prinsip kehatihatian, hal ini untuk mencegah timbulkan kredit macet. Untuk menumbuhkan dan meningkatkan keyakinan tersebut, bank selalu menggunakan analisis prinsip 5C, yaitu karakter (character), Kapasitas (capacity), Modal (capital), Jaminan (coleteral) dan Kondisi Ekonomi (condition of economy).
\end{abstract}

Kata Kunci: Perjanjian Kredit, Usaha Kecil, Perekonomian Masyarakat

\section{Bank Credit Agreement Between Small And Medium Businesses In Increasing Community Economy}

\begin{abstract}
Many small and medium business actors (UKM) in Indonesia still find it difficult to get capital from banks, because they do not understand the contents of the agreement and do not have collateral. The formulation of this research problem is how the credit agreement between the bank and SME actors, and the purpose of the study is to obtain information about the credit agreement between the bank and the actor. Use can provide information to Small and Medium Enterprises (SMEs) Research methods are normative juridical. The results showed that the implementation of the agreement carried out by BRI KCP Jati Asih could not be separated from the provisions of the Civil Code. Even though the credit agreement is not clearly regulated in the Civil Code, but the elements of the credit agreement cannot be separated from the provisions contained in the Civil Code. The
\end{abstract}

* E-mail: Ahmad.munawir1995@gmail.com 
agreement entered into by the bank with SMEs uses a standard contract. With a standard agreement, there is an imbalance in the position between the bank and the debtor, and also the clauses in the agreement are burdensome to the debtor. The conclusion that in the implementation of bank credit always follows the principle of prudence, this is to prevent bad credit. To foster and enhance these beliefs, banks always use the 5C principle analysis, namely character, capacity, capital, collateral and condition of economy.

Keywords: Credit Agreement, Small Business, Community Economy.

\section{Pendahuluan}

Dalam teori hukum perjanjian, kedudukan para pihak dalam perjanjian harus ada rasa keadilan. Ukurannya didasarkan pada kepatuhan para pihak dalam memenuhi semua isi perjanjian, artinya para pihak telah melaksanakan kewajibannya menurut yang sepatutnya, serasi dan layak menurut semestinya sesuai dengan ketentuan-ketentuan yang telah disepakati.

Keberadaan hukum perjanjian dalam peraktek, jika berjalan dengan normal akan menimbulkan keseimbangan para pihak yang berjanji, artinya para pihak dalam perjanjian memenuhi seluruh apa yang telah disepakati dan dibubuhkan dalam bentuk hukum perjanjian. Bila itu dapat berjalan dengan baik dan dilaksanakan dengan baik, maka hukum perjanjian akan dapat memberikan keadilan para pihak dalam perjanjian. Akhir dari pada tujuan hukum itu adalah keadilan.

Konteks keadilan dalam hukum perjanjian sebagaimana diatur dalam Pasal 1339 KUHPerdata : Perjanjian tidak hanya mengikat sesuai dengan apa yang disebut secara tegas, tapi juga segala apa saja yang diharuskan menurut sifat, kepatuhan, kebiasaan dan undang-undang. Artinya prasyarat dari isi perjanjian telah sesuai dengan apa telah diatur dalam kepatuhan, kebiasaan maupun ketentuan undang-undang.

Berkenaan dengan perjanjian, fungsi hukum perjanjian dalam kredit antara bank dengan pelaku usaha UKM harus dapat memberikan keadilan, hal ini sesuai dengan prinsip kredit yaitu saling keterbukaan antara pihak bank dengan nasabah dengan prinsip 5C, yaitu : Character (Watak), Capacity (Kemampuan), Capital (Modal), Collateral (Jaminan), dan Condition of Ekonomy (Kondisi 
Ekonomi). Prinsip ini sejalan dengan nilai-nilai keadilan dalam hukum, nilai keadilan dalam hukum salah satu adalah dapat menerima sesuai dengan apa yang diatur dalam perjanjian.

Hukum perjanjian sangat berperan dalam pemberian kredit antara bank dengan pelaku usaha kecil dan menengah (UKM), untuk meningkatkan perekonomian masyarakat. Sebab tujuan pemberian kredit itu mencakup proses alih keterampilan bidang produksi dan pengolahan, pemasaran, permodalan, sumber daya manusia sesuai dengan pola pemberian kredit, dengan prinsip saling mempercayai dan saling menguntungkan, maka bila tidak dibuat dengan sebuah perjanjian maka kepastian hubungan hukum para pihak tidak tercapai. Ketidakpastian itu akan berpengaruh terhadap hak dan kewajiban para pihak. Padahal sebuah hubungan hukum dibutuhkan sebuah kepastian, tanpa kepastian semua yang dilaksanakan para pihak tidak dapat berjalan secara optimal dan bahkan akan terjadi pemutusan hubungan secara sepihak tanpa sanksi.

Didalam Pasal 1313 KUHPerdata dikatakan bahwa perjanjian adalah suatu perbuatan dengan mana satu orang mengikatkan dirinya terhadap satu orang lain atau lebih. Seseorang atau lebih berjanji kepada seorang lain atau lebih saling berjanji untuk melakukan sesuatu hal. Ini merupakan suatu peristiwa yang menimbulkan satu hubungan hukum antara orang-orang yang membuatnya, yang disebut perikatan. Dengan demikian tampak jelas bahwa dalam suatu perikatan minimal dua orang terikat dalam suatu kesepakatan.

Perjanjian yang dibuat adalah undang-undang bagi para pihak yang berjanji, sebagaimana diatur dalam Pasal 1338 KUHPerdata : semua perjanjian yang dibuat secara sah berlaku sebagai undang-undang bagi mereka yang membuatnya. Perjanjian-perjanjian itu tidak dapat ditarik kembali selain dengan kesepakatan kedua belah pihak atau karena alasan-alasan yang oleh undangundang dinyatakan cukup untuk itu. Pasal 1320 KUHPerdata adalah syarat sahnya perjanjian, yaitu :

1. Adanya kesepakatan kedua belah pihak

2. Kecakapan untuk melakukan perbuatan hukum

3. Adanya obyek 
4. Adanya kausa yang halal.

Apabila perjanjian sudah disepakati para pihak dimana debitur sudah setuju, maka segala resiko harus ditanggung oleh debitur hal ini sesuai dengan pasal 1320 KUHPerdata. Syarat pertama sepakat, artinya apapun resiko dalam perjanjian itu secara hukum harus dapat dipertanggung jawabkan, dan seolaholeh disini pelaku UKM sudah melalui proses para pihak pembuatan perjanjian, padahal sepakat terjadinya tatkala pelaku UKM menandatangani naskah perjanjian, oleh sebab itu segala resiko dan kewajiban, dan akibat hukumnya maka pelaku UKM harus mentaatinya.

Pasal 1338 ayat (1) KUHPerdata menunjukkan kekuatan kreditur dan konsekwensinya perjanjian itu tidak dapat ditarik kembali secara sepihak. Namun kedudukan ini diimbangi dengan Pasal 1338 ayat (3) KUHPerdata yang menyebutkan bahwa perjanjian harus dilaksanakan dengan itikat baik. Hal ini memberi perlindungan pada para pihak yang melaksanakan perjanjian kredit menjadi seimbang. Ini merupakan realisasi asas keseimbangan dalam hukum.

Peranan perbankan dalam pengembangan usaha kecil dan menengah di Indonesia tentunya tidak terlepas keterkaitannya dengan cita-cita kemerdekaan Indonesia. Seperti yang tersimpul dalam Pembukaan Undang-Undang Dasar Republik Indonesia 1945, yang antara lain berbunyi : "Dan perjuangan pergerakan kemerdekaan Indonesia telah sampailah kepada saat yang berbahagia dan selamat sentausa mengantarkan rakyat Indonesia ke depan pintu gerbang kemerdekaan Negara Indonesia yang merdeka, bersatu, berdaulat, adil dan makmur".

Jelaslah sudah bahwa cita-cita kemerdekaan Indonesia adalah untuk mewujudkan masyarakat adil dan makmur. Ketentuan Undang-Undang Dasar 1945 ini janganlah hanya ditafsirkan sebagai penyediaan pekerjaan atas upah saja. Perkerjaan mandiri yang ditunjang oleh pemberian kredit adalah lebih potensial dalam pembentukan kekayaan daripada pekerjaan yang berdasarkan upah.

Pemberian kredit tidak lepas dengan perjanjian. Karena dalam melakukan suatu proses pemberian kredit maka harus dilakukan perjanjian. Perjanjian 
merupakan suatu persetujuan untuk melaksanakan suatu hal sesuai dengan isi yang disepakati oleh para pihak. Atas perjanjian ini para pihak dituntut untuk melaksanakannya karena perjanjian tersebut mempunyai hubungan hukum, karena hubungan hukum ini maka perjanjian tersebut memiliki kekuatan hukum di depan pengadilan

Perjanjian merupakan suatu hubungan hukum kekayaan/harta benda antara dua orang atau lebih, yang memberikan kekuatan hak pada satu pihak untuk memperoleh prestasi dan sekaligus mewajibkan pada pihak lain menunaikan prestasi (Widiyono, 2009 : 2).

Bagi perbankan setiap pemberian kredit yang disalurkan kepada pengusaha selalu mengandung risiko. Oleh karena itu, perlu unsur pengamanan dalam pengembaliannya. Unsur pengamanan (safety) adalah salah satu prinsip dasar dalam peminjaman kredit selain unsur keserasian (suitability). Bentuk pengamanan kredit dalam praktik perbankan dilakukan dengan pengikatan jaminan.

Dalam peraktek perbankan di Indonesian, pemberian kredit pada umumnya diikuti penyediaan jaminan oleh pemohon kredit, sehingga pemohon kredit yang tidak bisa memberikan jaminan sulit memperoleh kredit dari bank. Misalnya salah satu contoh dari kredit bank yaitu Kredit Usaha Kecil dan Menengah (UKM). Usaha kecil dan menengah adalah jenis usaha yang paling banyak jumlahnya di Indonesia, tetapi sampai saat ini batasan mengenai usaha kecil di Indonesia masih beragam. Jadi kredit UKM adalah peminjaman uang kepada bank yang dilakukan oleh pengusaha untuk melancarkan kegiatannya didalam bidang usahanya, tetapi kegiatan usahanya hanya yang berbentuk kecil atau menengah. Dari segi ini, didefenisikan bahwa pengusaha kecil adalah usaha berbentuk perseorangan, bisa berbadan hukum yang didalamnya termasuk koperasi.

Sektor UKM merupakan komponen penting bagi upaya pemberdayaan ekonomi rakyat. Ini terbukti bahwa sektor UKM secara potensial mempunyai modal sosial untuk berkembang wajar dan bertahan disemua kondisi, relatif mandiri karena tidak tergantung pada dinamika sektor moneter secara nasional. 
Bahkan mempunyai potensi yang besar menyerap tenaga kerja penyumbang devisa penghasil berbagai barang murah dan terjangkau oleh kekuatan ekonomi rakyat dan distribusinya menyebar luas. Usaha kecil merupakan bagian integral dari dunia usaha nasional yang mempunyai kedudukan, potensi dan peranan yang sangat strategis dalam mewujudkan tujuan pembangunan nasional.

Berdasarkan latar belakang masalah yang telah diindentifikasi dan ditegaskan dalam pembatasan masalah maka dapat dirumuskan masalah yaitu : bagaimana perjanjian kredit antara bank dengan pelaku usaha kecil dan menengah (UKM) dalam rangka pemberian modal tanpa jaminan?

\section{Pembahasan}

\section{A. Perjanjian Kredit Antara Bank Dengan Nasabah}

Dalam pelaksanaan perjanjian kredit antara nasabah dengan pihak bank yang terjadi di BRI KCP Jati Asih tidak lepas dari ketentuan Hukum Perdata. Hal ini sesuai dengan hasil penelitian penulis dari perjanjian yang dibuat oleh nasabah dengan pihak bank.

Hasil penelitian penulis bahwa semua perjanjian yang dibuat oleh para pihak tidak lepas dari ketentuan Kitab Undang-Undang Hukum Perdata. Perjanjian atau Overeenkomst di dalam Pasal 1313 menyebutkan "suatu perbuatan dengan nama atau satu orang lebih mengukatkan dirinya terhadap satu orang lain atau lebih".

Suatu perjanjian adalah suatu perhubungan hukum mengenai harta benda antara dua pihak, dimana satu pihak berjanji atau dianggap berjanji untuk melakukan sesuatu hal, sedangkan pihak lain berhak menuntuk pelaksanaannya. Supaya perjanjian mempunyai kekuatan hukum, haruslah memenuhi syarat sahnya perjanjian yang terdapat dalam Pasal 1320 Kitab Undang-Undang Hukum Perdata, yakni :

1) Sepakat mereka yang mengikatkan dirinya

2) Kecakapan untuk membuat suatu perikatan

3) Suatu hal tertentu 
4) Suatu sebab yang halal

Keempat syarat perjanjian tersebut merupakan syarat mutlak yang harus dipenuhi untuk syahnya suatu perjanjian, apabila salah satu syarat tersebut tidak dipenuhi maka perjanjian tersebut dengan sendirinya batal (nietig). Bilamana kesepakatan terjadi disebabkan karena adanya kesesatan (dwaling), paksaan (dwang) dan penipuan (bedrog) maka perjanjian tersebut dapat dimintakan pendaftaran (vernieteg verbaar) kepada hakim dan apabila kesepakatan diberikan dengan secara tidak bebas, sehingga salah satu pihak dianggap tidak cakap untuk melakukan perbuatan hukum sendiri, maka perjanjian itu adalah cacat dan karenanya dapat dibatalkan oleh hakim atas permintaan pihak yang telah memberikan kesepakatannya dengan secara tidak bebas atau oleh orang yang tidak cakap membuat perjanjian tersebut.

Perjanjian kredit yang dibuat di Bank BRI KCP Jati Asih tercipta tatkala adalah perjumpaan kehendak, dimana pihak nasabah membutuhkan modal, sedangkan pihak bank membutuh konsumen, hal ini penting agar perputaran uang berjalan dengan baik. Prinsip dalam perjanjian yang dibuat bersifat konsensual yang dilandasi dalam Pasal 1320 KUHPerdata (Agustina dkk, 2012 : 80). Untuk itu suatau perjanjian cukup dengan kata sepakat sehingga perjanjian menjadi mengikat dan tidak perlu lagi suatau formalitas pembuktiannya.

Menurut ketentuan Pasal 1338 Ayat (1) "semua perjanjian yang dibuat secara sah berlaku sebagai undang-undang bagi mereka yang membuatnya”. Dalam pasal ini memuat azas kebebasan berkontrak, azas ini menentukan bahwa setiap orang adalah bebas untuk membuat perjanjian berupa dan berisi apa saja. Akan tetapi kebebasan berkontrak ini dibatasi oleh hukum yang sifatnya memaksa sehingga para pihak yang membuat perjanjian harus mentaati hukum yang sifatnya memaksa tersebut, misalnya terhadap Pasal 1320 KUHPerdata. Secara jelas juga dalam pasal 1338 ayat (1) bahwa perjanjian demikian mengikat dan berlaku sebagai hukum bagi para pihak (Agustina dkk, 2012 : 80).

Pasal 1338 Ayat (2) memuat azas kekuatan yang mengikat, pasal ini menyebutkan bahwa persetujuan-persetujuan tidak dapat ditarik kembali selain dengan kata sepakat kedua belah pihak atau karena alasan-alasan yang oleh 
undang-undang dinyatakan cukup untuk itu. Dengan demikian, azas ini menetapkan secara tegas bahwa suatau perjanjian akan mengikat para pihak dalam perjanjian yang dibuatnya. Penarikan kembali atau pengakhiran oleh salah satu pihak hanyalah mungkin pada perjanjian dimana oleh kedua belah pihak disetujui untuk suatau waktu yang tidak tertentu diizinkan pengakhirannya, dengan tidak usah menyebutkan suatu alasan apapun. Azas kekuatan mengikat ini ada hubungannya dengan pasal 1339 jo, 1347 KUHPerdata mengenai kebiasaan dan kepatutan yang secara diam-diam dianggap dalam perjanjian.

Pasal 1338 Ayat (3) memuat azas itikad baik, pasal ini menyebutkan bahwa persetujuan-persetujuan haruslah dilaksanakan dengan itikad baik, artinya perjanjian ditafsirkan sedemikian rupa sehingga dapat dilaksanakan dan diterima semua pihak dan dirasakan oleh masyarakat sebagai suatau keadilan dan kepastian hukum.

Menurut Subekti, semua pemberian kredit pada hakekatnya merupakan perjanjian pinjam-meminjam sebagaimana diatur dalam Pasal 1754 s/d 1769 KUHPerdata (Subekti, 1987 : 3). Perjanjian pinjam-meminjam adalah suatau perjanjian dengan mana pihak yang satu memberikan kepada pihak yang lain suatu jumlah tertentu barang-barang yang habis karena pemakaian, dengan syarat bahwa pihak yang terakhir ini mengembalikan sejumlah yang sama dari jenis dan mutu yang sama pula ( Pasal 1754 KUHPerdata ). Dalam hal ini, Subekti melihat kredit sebagai suatu hal yang umum. Sementara perjanjian kredit yang diberikan oleh bank memiliki karakteristik yang khusus, terutama berkaitan dengan konsep utang.

Meskipun perjanjian kredit tidak diatur secara tegas dan khusus dalam KUHPerdata, unsur-unsur perjanjian kredit tidak boleh bertentangan dengan prinsip-prinsip yang diatur oleh KUHPerdata. Hal ini ditegaskan dalam Pasal 1319 KHUPerdata yang menyatakan bahwa semua perjanjian, baik yang mempunyai nama khusus maupun yang tidak dikenal dengan suatau nama khusus harus tunduk pada peraturan-peraturan umum yang termuat dalam Bab I dan Bab II KUHPerdata. 
Sesuai dengan isi perjanjian yang dibuat oleh para pihak, maka diatur ketentuan mengenai hak dan kewajiban, hasil diskusi penulis dengan Bambang Wagito selaku pimpinan BRI KCP Jati Asih tentang hak dan kewajiban para pihak yang termuat dalam isi perjanjian, menurut beliau mengenai kalusul hak dan kewajiban para pihak dalam isi perjanjian ialah :

a. Hak dan Kewajiban Kreditur dalam isi perjanjian

1) Hak kreditur dalam isi perjanjian.

a) Pihak kreditur berhak menerima pengembalian kredit yang disalurkan kepada debitur, baik dalam bentuk angsuran maupun bentuk lain yang telah disepakati oleh kedua belah pihak. Apabila debitur lalai dalam artian menunggak lebih dari 3 (tiga) bulan, maka pihak kreditur dapat meminta konfirmasi melalui pendekatan personal secara langsung kepada pihak debitur.

b) Pihak kreditur berhak menentukan pola angsuran yang harus dibayarkan oleh debitur.

c) Pihak kreditur berhak memberikan sanksi yang tegas kepada debiturnya apabila debitur melakukan wanprestasi.

2) Kewajiban kreditur dalam isi perjanjian.

Pihak kreditur berkewajiban untuk menyerahkan sejumlah uang yang telah diperjanjikan sebelumnya sebagai pinjaman kredit. Bambang Wagito mengatakan bahwa BRI KCP Jati Asih juga mempunyai kewajiban yang mungkin tidak setiap bank menerapkannya, yaitu melakukan pembinaan atau arahan.

b. Hak dan Kewajiban Debitur dalam isi perjanjian

1) Hak Debitur dalam isi perjanjian

Pihak debitur berhak menerima sejumlah uang pinjaman dengan waktu yang telah disepakati kedua belah pihak. Jumlah uang pinjaman yang diberikan berdasarkan pada tingkat kelancaran usaha yang dijalankan oleh debitur.

2) Kewajiban debitur dalam isi perjanjian. 
Pihak debitur bekewajiban untuk mengembalikan seluruh pinjaman kredit yang telah dipinjamkan disertai dengan bunga yang telah ditentukan. Menurut keterangan pimpinan BRI KCP Jati Asih, debitur tidak dibebankan biaya-biaya lain seperti administrasi. Selain itu debitur juga diwajibkan mematuhi semua aturan yang telah dicantumkan dalam formulir pengajuan permohonan kredit dan aturan-aturan yang telah ditetapkan oelah BRI KCP Jati Asih.

Penulis berkesimpulan, dari hak dan kewajiban yang ada dalam isi perjanjian tidak seimbang. Disatu sisi bank mempunyai hak yang lebih besar dan banyak bila dibandingkan dengan hak debitur, sedangkan kewajiban bank lebih sedikit bila dibandingkan dengan kewajiban debitur.

Selain itu juga diatur dalam perjanjian kredit mengenai cara pembayaran kredit hal sesuai dengan hasil wawancara penulis dengan pimpinan BRI KCP Jati Asih, yang menyebutkan bahwa pembayaran kembali kredit dilakukan secara angsuran bulanan, yang terdiri dari angsuran pokok kredit dan angsuran bunga, sedemikian rupa sehingga seluruh jumlah kredit terhutang dilunasi pada akhir jangka waktu kredit.

\section{B. Prosedur Pemberian Kredit Melalui Perjanjian Kredit Oleh Bank Kepada Pelaku Usaha Kecil dan Menengah (UKM)}

Dari hasil penelitian penulis di Bank BRI KCP Jatiasih bahwasanya ada kredit bagi pelaku UKM tanpa jaminan/atau agunan. Kredit ini disebut Kredit Usaha Rakyat (KUR). Namun krdit dengan tanpa jaminan ini tidak terlalu besar hanya untuk plafon 5 juta sampai dengan 25 juta saja. Kredit Usaha Rakyat tersebut terbagi atas :

a. KUR Mikro yaitu kredit dari plafond Rp. 5.000.000 sampai dengan Rp. 25.000.000 saja. Dari hasil diskusi penulis dengan pimpinan cabang Bank BRI KCP Jatiasih bahwa ini adalah kredit tanpa jaminan. Tanpa jaminan disini bukan sama sekali tidak ada jaminan, hanya saja usaha dari pelaku 
UKM lah yang menjadi Jaminan dasar untuk peminjaman kredit. dari hasil yang penulis dapat bahwasanya di Bank BRI KCP Jatiasih ternyata KUR tanpa jaminan tersebut hanya sampai plafond 10 Juta saja, sebab Bank BRI KCP Jatiasih memiliki kebijakan untuk plafond diatas 10 juta sampai 25 juta menggunakan jaminan tambahan seperti BPKB motor dan sejenisnya.

b. KUR Ritel yaitu kredit dari plafond diatas Rp. 25.000.000 sampai dengan Rp. 500.000.000 . Kredit ini sudah menggunakan jaminan asset dan sejenisnya.

c. KUR Linkage Program yaitu kredit plafond diatas Rp. 500.000.000 sampai dengan Rp. 2.000.000.000 . Kredit ini adalah kredit yag terbesar dari KUR yang ada dan menggunakan nilai jaminan yang besar juga.

Kebutuhan akan keperluan kredit mempunyai berbagai corak ragam alasan dan latar belakang. Perorangan, perusahaan, negara atau bangsa di dunia ini mempunyai berbagai kepentingan dan alasan untuk berusaha dengan aneka jalan untuk mendapatkan kredit (Tjiptonugroho, 1994 : 16).

Berdasarkan hasil penelitian penulis di kantor BRI cabang pembantu Jatiasih yang dipimpin oleh bapak Bambang wagito selaku pimpinan cabang pembantu, maka penulis dapat mengemukakan salah satu kredit yang diambil kebanyakan pelaku usaha kecil dan menengah (UKM) ialah kredit usaha rakyat. Perjanjian kredit tersebut dilakukan secara bertahap, yaitu :

\section{a. Tahap Permohonan Kredit}

Calon debitur mengajukan permohonan kredit secara tertulis kepada pihak BRI cabang pembantu Jatiasih. Permohonan kredit tersebut berbentuk perjanjian baku, dimana formulir sudah disediakan oleh pihak bank, dengan demikian calon debitur hanya tinggal mengisi bagian kosong yang perlu diisi beserta tanda tangan dalam formulir tersebut tanpa proses negosiasi syarat-syarat yang ada dalam permohonan tersebut. Kredit usaha rakyak yang bisa diambil oleh Usaha kecil dan menengah iyalah 5 juta sampai dengan 25 juta tanpa jaminan dan 25 juta keatas dengan jaminan.

Calon debitur diharuskan memenuhi persyaratan yang telah ditetapkan dalam hal pengajuan permohonan kredit tanpa jaminan maupun dengan 
jaminan. KUR tanpa jaminan diperkenalkan dengan kredit yang mudah didapat dengan syarat-syarat yang ditetapkan pun sederhana. Syarat-syarat yang perlu disertakan adalah bukti identitas diri berupa foto kopi Kartu Tanda Penduduk (KTP) dan foto kopi Kartu Keluarga (KK) serata surat ijin usaha untuk KUR diatas 25 juta.

\section{b. Tahap Peninjau dan Analisis Kredit}

Bank harus melakukan analisa kredit terlebih dahulu sebelum menyalurkan kredit. Analisa kredit adalah penelitian yang dilakukan oleh Account Officer terhadap kelayakan usaha nasabah, kebutuhan keredit, kemampuan menghasilkan laba, sumber pelunasan kredit serta jaminan yang tersedia untuk menjmin permohonan kredit.

Setiap bank mempunyai hampir sama standart untuk prosedur permohonan kredit baik itu bank swasta maupun bank pemerintah, termasuk dalamnya Bank Rakyat Indonesia (BRI). BRI mempunyai prosedur standart untuk permohonan kredit. kalau diperhatikan berkas permohonan kredit sama seperti apa yang ditulis oleh Thomas Suyatno Dkk, dalam bukunya Dasar-Dasar Perkreditan antara lain menyebutkan (Suyatno dkk, 1997 : 70):

1) Surat-surat permohonan nasabah yang ditandatangani secara lengkap dan sah.

2) Daftar isian yang disediakan oleh bank yang secara sebenarnya dan lengkap diisi oleh nasabah.

3) Daftar lampiran lainnya yang diperlukan menurut jenis fasilitas kredit.

Hambatan yang paling sukar oleh pelaku usaha ialah pengisian formulir perjanjian kredit maupun pengisian data-data merupakan hal yang asing bagi pemohon kredit khususnya pelaku UKM. Orang-orang yang belum pernah atau belum biasa dengan teknik suasana perbankan, merasa dirinya "kecil" menghadapi sistem kredit formal ini. Perasaan ini akan mengurangi gairahnya untuk mendapatkan kredit yang dimohonkannya.

Bagaimanapun arahan diatas, tetap terbuka peluang bagi bank-bank untuk mengatur kebijakan kreditnya sesuai dengan kondisi dan kebutuhan 
bank itu sendiri. Bank BRI cabang pembantu jatiasih dalam melakukan analisis kredit pun mempunyai kebijan sendiri yang tentunya teteap berpedoman pada arahan Bank Indonesia. Laporan Keuangan (financial statement) calon debitur merupakan salah satu data pokok mutlak dalam hal analisis.

Pada tahap ini setelah syarat-syarat dilengkapi, pihak bank akan melaksanakan cheking antara Kartu Tanda Penduduk (KTP) dan pemohon. Segmen BRI cabang pembantu Jatiasih adalah masyarakat yang berdomisili di Bekasi ataupun mreka yang tidak berdomisili di bekasi tetapi memiliki usaha di bekasi, sehingga untuk calon debitur yang berdomisili di luar Bekasi yang hendak mengajukan kredit tanpa jaminan di Bank BRI cabang pembantu Jatiasih untuk terlebih dahulu mendapat ijin dari BRI tempatnya bedomisili. Hal ini dilakukan untuk menghindari penyalahgunaan yang dapat dilakukan untuk menghindari penyalahgunaan yang dapat dilakukan oleh calon debitur melalui double credit.

Selanjutnya dilakukan penelitian dan peninjauan langsung kepada calon debitur serta segala sesuatu yang telah disyaratkan dalam hubungannya dengan informasi-informasi dan usaha calon debitur. Penelitian terhadap usaha dapat berupa usaha yang masih terencana ataupun usaha yang telah direalisasi. Informsi ini diperoleh melalui banyak cara, yaitu dengan menanyakan kepada tetangga terdekat dari tempat tinggal atau tempat usaha calon debitur baru tersebut. Semua langkah tersebut dilakukan dalam rangka memperoleh hasil analisa permohonan kredit yang akurat. Usaha menjadi faktor terpenting dalam perjanjian kredit tanpa jaminan, ini karena usaha menjadi jaminan pokok perjanjian kredit ini.

Dalam hal ini, yang bertugas untuk melakukan analisis dan pengamatan langsung kepada calon debitur adalah seorang mantra atau biasa disebut Account Officer (AO). Selanjutnya mantri akan menganalisis dalam aspek character yang merupakan penilaian terhadap karakter debitur, disamping itu juga meneliti usahanya. Mantra kemudian membuat laporan 
secukupnya mengenai analisisnya tersebut untuk diputuskan apakah dapat atau tidak permohonan kredit tersebut dikabulkan.

Menurut Bambang Wagito yang bertindak sebgai kepala cabang pembantu Jatiasih, besaran kredit yang diberikan oleh pihak bank didasarkan pada usaha calon debitur yang dijalankan. Disamping melihat dari sisi usahanya, hal lain yang tidak kalah penting adalah aspek character. Melalui aspek ini, mantra bisa menilai apakah calon debitur pada nantinya dapat melaksanakan pemenuhan prestasinya atau tidak.

\section{c. Tahap Pemberian Keputusan Kredit}

Pada tahap ketiga ini, calon debitur akan memperoleh keputusan kredit yang berisi persetujuan akan adanya pemberian kredit tanpa jaminan amaupun dengan jaminan sesuai dengan permohonan yang diajukan. Keputusan persetujuan permohonan kredit berupa mengabulkan sebagian atau seluruh permohonan kredit dari calon debitur. Pihak bank BRI cabang pembantu Jatiasih akan memberitahukan kesetujuan atau tidaknya dalam meberikan kredit pada calon debitur, dengan meberitahu kepada calon debitur untuk mengkonfirmasi kembali beberapa hari menururt hari yang telah ditentukan oleh pihak bank setelah pengajuan permohonan kredit.

Setiap pejabat yang terlibat dalam kebijakan persetujuan kredit harus mampu memastikan hal hal berikut (Firdaus dan Ariyanti, 2003 : 51) :

1) Setiap kredit yang diberikan telah sesuai dengan prinsip perkreditan yang sehat dan ketentuan perbankan lainnya.

2) Pemberian kredit telah sesuai dan didasarkan pada analisis kredit yang jujur, objektif, cermat, dan seksama (menggunakan prinsip 5C) serta independent.

3) Adanya keyakinan bahwa kredit akan mampu dilunasi oleh debitur.

\section{d. Tahap Perjanjian Kredit}

Pada tahap ini calon debitur datang langsung ke kantor BRI cabang pembantu Jatiasih berdasarkan waktu yang telah ditentukan oleh pihak bank. Setelah disetujui, debitur menandatangani lembar kesepakatan yang 
telah disediakan oleh pihak bank. Bersamaan dengan penandatanganan itu pula, lahirlah hak dan kewajiban yang harus dipenuhi masing-masing pihak.

\section{e. Tahap Pencairan Kredit}

Dalam setiap pencairan kredit harus terjamin azas aman, terarah, dan produktif dan diaksanakan apabila syarat yang ditetapkan dalam perjanjian kredit telah dipenuhi oleh pemohon kredit (Firdaus dan Ariyanti, 2003 : 52). Setelah semua persyaratan terpenuhi dan pemberian kredit diikat oleh perjanjian kredit maka debitur dapat mengambil dana pinjaman yang telah dimohonkan kepada bagian teller BRI cabang pembantu Jatiasih. Waktu lama proses permohonan kredit hingga tahap pencairan dana mempunyai batas normal antara 2 sampai 7 hari.

Gatot Supramono memberikan pendapat bahwa lamanya proses pencairan dana, disebabkan pula oleh penerapan asas kehati-hatian dalam menyalurkan dananya dan teteap berpegang teguh pada lima prinsip dalam penelitian kondisi nasabah atau sering disebut the five of credit analysis (Supramono, 1995 : 33-34). 5 C itu antara lain Character, capacity, capital, collateral, condition of economy.

Setelah melalui tahapan-tahapan diatas, secara otomatis perjanjian kredit telah lahir setelah ditandatanganinya kesepakatan kedua belah pihak, yaitu pihak debitur dan pihak bank BRI cabang pembantu Jatiasih dimana debitur juga sudah menerima penyerahan uang atas pinjamannya dari pihak bank. Hal ini sesuai dengan sifat perjanjian kredit itu sendiri yaitu bersifat konsensuil-obligatoir.

Sifat konsensuil dari perjanjian kredit itu ada setelah tercapai kesepakatan diantara pihak bank dengan debitur yang dituangkan dalam bentuk penandatanganan perjanjian kredit itu sendiri. Sedangkan sifat obligatoir terlihat dengan adanya hak dan kewajiban yang timbul karena adanya perjanjian kredit, yaitu bank selaku kreditur yang mempunyai kewajiban menyerahkan uang kepada debitur dan debitur menerimanya. 


\section{Perjanjian Kredit Antara Bank Dengan Pelaku Usaha Kecil dan Menengah (UKM) Sebagai Perjanjian Baku.}

Dilihat dari bentuknya bahwa perjanjian kredit perbankan pada umumnya mempergunakan bentuk perjanjian baku (standart contract). Perjanjian baku ini sudah lama menjadi masalah. Kelemahan perjanjian baku ini adalah mengenai sifat (karakternya), karena ditentukan secara sepihak dan didalamnya ditentukan sejumlah klausula yang membebaskan kreditur dari kewajibannya atau eksonarisasi klausula (Untung, 2000 : 112-113) juga dikemukakan dalam kenyataan secara kenyataan atau depacto, isi perjanjiannya tidak diketahui oleh pihak yang disodori perjanjian standar, ini menjadi salah satu alasan pokok keberatan. Kenyataan juga bahwa kalaupun mereka (debitur) tahu isinya, belum tentu mereka tahu maksud dan jangkauan daripada klausula-klausula yang ada dalam perjanjian tersebut.

Kalau dicermati perincian keberatan tersebut antara lain telah dituangkan dalam satu formulir, isinya tidak sama sekali dimusyawarahkan atau bahkan diperbincangkan. Pihak yang disodori perjanjian hanya memiliki dua pilihan, kalau setuju perjanjian dilaksanakan dan kalau tidak setuju maka perjanjian batal. Akibat kebutuhan maka sering dengan terpaksa debitur atau konsumen menerima keadaan itu karena posisinya yang lemah.

Dari data perjanjian yang penulis lihat di Bank BRI kantor cabang pembantu Jatiasih memang benar dalam perjanjian kredit tersebut mempergunakan bentuk perjanjian baku. Dari diskusi penulis dengan pimpinan cabang pembantu bank BRI dengan bapak Bambang Wagito, beliau membenarkan bahwa perjanjian kredit di bank tersebut menggunakan perjanjian baku (standart contract). Dari paparan beliau penulis menyimpulkan bahwa dilakukannya perjanjian baku itu adalah dengan beberapa pertimbangan, yaitu :

a) Mempercepat proses perjanjian agar para nasabah dapat dengan cepat mencairkan dana pinjaman untuk digunakan sebaik mungkin.

b) Salah satu bentuk prinsip kehati-hatian dari bank untuk memperkecil risiko bank dalam perjanjian dimana bank berada dalam posisi yang kuat. 
c) Agar bank dapat mengendalikan risiko untuk memperkecil kemungkinan terjadinya kredit macet atau beberapa risiko lain yang merugikan pihak bank.

Di Indonesia belum ada ketentuan undang-undang maupun yurisprudensi yang secara spesifik memberikan aturan-aturan dasar yang harus di perhatikan apabila suatu pihak dalam suatu perjanjian menghendaki agar suatu klausul yang memberatkan dalam perjanjian baku berlaku bagi hubungan hukum antara pihaknya dengan mitra janjinya.

Namun secara operasional menurut penulis dasar hukum perjanjian baku itu adalah Pasal 1320 KUHPerdata, dimana syarat pertama disebutkan kata sepakat, artinya jika perjanjian itu telah disepakati maka perjanjian tersebut syah secara hukum

Memang dalam pengamatan penulis kata sepakat ini mengandung arti yang beragam, hasil diskusi dengan salah satu Devisi Hukum dan Hubungan bank BRI serta pimpinan cabang BRI Jatiasih, mengemukakan bahwa meskipun perjanjian itu dibuat tanpa melalui proses kedua belah pihak dan beberapa hal lainnya yang artinya bahwa isi perjanjian bukan hasil buah pikiran para pihak, tetapi jika para pihak telah sepakat akan isi perjanjian tersebut dan telah ditanda tangani, maka perjanjian itu syah menurut hukum.

Penulis berkeyakinan meskipun perjanjian itu baku, namun jika para pihak telah sepakat dan telah menandatangani isi perjanjian itu, maka perjanjian itu syah menurut hukum.

\section{Penutup}

\section{A. Kesimpulan}

Perjanjian kredit antara bank dengan pelaku usaha kecil dan menengah (UKM) di BRI KCP Jati Asih dalam pelaksanaannya tidak lepas dari ketentuan Hukum Perdata. Walau didalam KUHPerdata tidak diatur secara tegas dan khusus mengenai perjanjian kredit, namun unsur-unsur perjanjian kredit tidak boleh bertentangan dengan prinsip-prinsip yang diatur oleh KUHPerdata. Dalam 
perjanjian kredit yang dibuat oleh Bank Rakyat Indonesia (BRI) adalah perjanjian baku (standart contract) dimana pihak bank sudah mempersiapkan perjanjian dalam bentuk form yang dimana isi klausulnya tidak dapat diubah oleh pihak debitur.

\section{B. Saran}

Pemerintah harus lebih memperhatikan pelaku Usaha Kecil dan Menengah (UKM). Pemeliharaan dan pemodalan terhadap UKM sangatlah penting sebab jangka panjang terhadap hal itu akan meningkatkan perekonomian masyarakat. Dalam hal informsasi, dimana salah satunya yang sedang marak sekarang adalah Kredit Usaha Rakyat (KUR) agar pemerintah memantau agar pelaku UKM mengetahui dan paham tentang perkeditan tersebut.

\section{Daftar Pustaka}

Agustina, Rosa, dkk, Hukum Perikatan (Law of Obligations), Denpasar : Pustaka Larasan, 2012.

Firdaus, Rachmat, dan Maya Ariyanti. Manajemen Perkreditan Bank Umum. Bandung : Alfabeta. 2003.

R. Tjiptoadinugroho, Perbankan Masalah Perkreditan (Penghayatan, Analisis dan Penuntun). Jakarta : Pradnya Paramita, 1994.

Raharjo, Satjipto. Permasalahan Hukum di Indonesia, Bandung : Alumni 1983.

Subekti, Jaminan-Jaminan Untuk Pemberian Kredit Menurut Hukum Indonesia, cet. Ke-5, Bandung : Alumni, 1987.

Suyatno, Thomas, dkk, Dasar-Dasar Perkreditan Edisi Keempat, Diterbitkan oleh kerjasama sekolah tinggi Ilmu Ekonomi Perbanas, Jakarta : Gramedia Pustaka Utama, 1997.

Supramono, Gatot. Perbankan dan Masalah Kredit. Jakarta : Djamban, 1995.

Untung H, Budi. Kredit Perbankan Indonesia, Yogyakarta : Penerbit Andi. 2000. 
Widiyono, M. Yahya. Agunan Kredit Dalam Financial Engineering, Ghalia Indonesia, 2009.

Indonesia. Undang-undang Dasar Negara Republik Indonesia Tahun 1945

ـ Kitab Undang-undang Hukum Perdata 